\title{
VÍZKÉP-ÖKOLÓGIAI AKCIÓ \\ - KÖRNYEZETI PROBLÉMA ÉRTELMEZÉSE-OLVASÁSA \\ TANTÁRGYKÖZI MÓDSZEREK ALKALMAZÁSÁVAL A VALÓS TÁRSADALMI TÉRBEN
}

\author{
Szerző: \\ Vályi Péter (Drs) \\ Eszterházy Károly Egyetem
}

Szerző e-mail címe:

valyipeti@gmail.com

\author{
Lektorok: \\ Varga Attila (PhD) \\ Eszterházy Károly Egyetem-OFI \\ Mező Katalin (PhD) \\ Debreceni egyetem
}

...és további két anonim lektor

\begin{abstract}
Absztrakt
Korunk globális válsághelyzetének a megértésében, megismerésében minden iskolai tantárgynak fontos szerepe van. Ahogy a tantárgyak egymással való összekapcsoltságának esetében egyre kevésbé lehetséges „sávosan” gondolkodni, úgy a globális válsághelyzet nyomán a környezeti neveléssel összekapcsolható tárgyak esetén sem célszerű releváns és irreleváns tantárgyközi vonatkozásokról beszélni. Tantárgy ökológia kapcsán, nemcsak a tantárgyak tereiről beszélhetünk, hanem módunkban áll azok közötti összekapcsoltságról, átjárhatóságról, egymásrautaltságról is beszélni. Havas és Lehoczky szerint a művészeteknek fontos szerepe van a természetről, környezetről való gondolkodás esetében, értelmezésük főként az esztétikai dimenzió terén látja annak szerepét (Havas 1994, Lehoczky 1999), azonban, ahogy a művészeti nevelés önmagában többre predesztinált, mint a látásra nevelés, úgy a művészeti oktatás funkciója is többet jelent környezeti nevelés vonatkozásban, mint újraalkotás, esztétikai élmény, színek kavalkádja.
\end{abstract}

Kulcsszavak: tantárgy ökológia, környezeti nevelés, vizuális nevelés

Diszciplinák: pedagógia, filozófia, művészet

\author{
Abstract \\ WATER PICTURE-ECOLOGICAL ACTION \\ - READING AND INTERPRETING AN ENVIRONMENTAL PROBLEM \\ USING CROSS-CURRICULAR METHODS IN REAL SOCLAL SPACE
}

All subjects of education are important in the process of recognition and learning the phenomena of global crisis. As in the case of interconnections of subjects it is pointless 
or unsuitable to think on those like distinct paths, so it is also unsuitable to think on relevant or irrelevant intersubjectical connections between environmental education and other kontents by lerning about global crisis. In ecology of subjects there is much more to say, like interconnectedness, interdisciplinarity, interdependence, as only space of those. Havas and Lehoczky arguing that artistic education is important by stimulating behavoir or feelings on nature or environment, in their concept art becomes important just in an aestethical dimension (Havas, Lehoczky). However as artistic education itself is predestinated on much more as the „education of view”, therefore artistic practice has a higher scaled function in environmental education like remaking, aestethical experience and rush of colors.

Keywords: ecology, environmental education, visual education

Disciplines: pedagogy, philosophy, art

Vályi Péter (2020): Vízkép-ökológiai akció - Környezeti probléma értelmezése-olvasása tantárgyközi módszerek alkalmazásával a valós társadalmi térben. OxIPO - interdiszciplináris tudományos folyóirat, 2020/1, 71-83. doi: 10.35405/OXIPO.2020.1.71

\section{Bevezetés, elméleti keretek}

Bevezetésként fontos tisztázni, hogy az alábbiakban bemutatásra kerülő környezeti akció nem illeszkedik azon iskolai akciók, vagy pedagógiai kutatások sorába, amelyek a környezeti probléma diagnosztikáját követően orvosolni kívánják azt egyfajta cselekvésen keresztül. Továbbá ez az akció, nem mutat rokonságot azokkal a környezeti attitűdök vizsgálatára fókuszáló kutatásokkal sem, amelyek a tanulók környezettel szembeni viselkedését, meggyőződéseit, érzelmi, intellektuális relációit kívánják vizsgálni. Ugyanakkor a bemutatásra kerülő környezeti akció egyrészt szakítás bizonyos máig érvényes oktatási, kutatási trendekkel, másrészt „újraélesztése” annak az iskolai tevékenységnek, amely az ismeret-, vagy tapasztalatszerzés élményére, annak körülményeire, legtágabb lehetőségeire fókuszál.

A pedagógiai, ökológiai akció elméleti hátteréül az utóbbi évtizedben egyre dominánsabbá váló filozófiai keretrendszer, az OOO, (magyar fordításban objetum-, vagy tárgyorientált ontológia - Harman, 2002) szolgál, amely szakít az antropocentrikus világnézet máig domináns, emberi akaratnak mindent alárendelő és komplexnek, megismerhetőnek tekintett világ- és tudományfilozófiai koncepciójával. A jelen filozófiai keretrendszer letaszítja a humán szubjektum ideált eddigi, hierarchia csúcsán elfoglalt helyérôl, illetve megfosztja azt minden hozzárendelt privilégiumától. Új helyét a valóságot, világot alkotó 
jelenségek (jelen filozófia esetében tárgyakobjektumok) sorában határozza meg, Bryant szavaival élve, egy lapos, horizontálisan elterülő demokráciában (Bryant, 2011). A hierarchikus elrendeződéssel ellentétes, heterarchikus szerveződési forma a kognícióra, tudományra, tudományfilozófiára is hatást gyakorol, hiszen az ember új helyéból adódóan a tárgyak, tárgyak alkotta valóság egy, vele szemben álló oldalát látja mindössze egy adott pillanatban, s így ismeretei szekvenciálisak, részlegesek csupán (Harman, 2002). A valóság megismerését azonban segíti az interobjektivitás jelensége, illetve annak fogalma, amely annyit mond ki röviden, hogy az egyes tárgyak, vagy azok hatásai visszacsillannak, felsejlenek más tárgyak minőségében, tulajdonságaiban (Harman, 2002, Morton, 2013). A tárgyorientált ontológia önmagában egy szigorú filozófiatudománnyal, tudományfilozófiával, kognitív tudományokkal szembeni non-antropocentrikus kritikai megközelítés. Ez azonban Timothy Morton jóvoltából ökológiai, globális ökológiai krízishelyzet vonatkozásában is kibontásra került az elmúlt 13 évben, így annak környezeti nevelésbe történő átültetése korán sem jelent nehéz-séget (Morton 2007, 2010, 2013, 2016, 2017, 2018).

Neveléstudomány vonatkozásában jelen akció fontosnak tartja Dawid W. Orr azon modern pedagógiára vonatkozó kritikáját, amely szerint a civilizatorikus, techno optimista pedagógiai koncepció számtalan veszélyt hordoz magában és korán sem egyenlő a személyiség szükséges fejlesztésével (Havas, 1994, Orr, 2004, Takács-Sánta, 2007). A tantárgyak, tudományterületek sávos, egymástól gondosan elhatárolt, rendszerszintű betekin- tést, vagy rálátást eleve ellehetetlenítő elrendezésének kritikájával is egyetért és amellett érvel, hogy minden kapcsolatban áll mindennel (Havas, 1994; v.ö.: az OxIPO-modell szerinti tanulásmódszeran holisztikus tanulást ajánló módszeranával - Mező, 2011). Intézmény, vagy közösségszervezési vonatkozásban támogatja a Varga által összeállított iskolatipológia azon megközelítését, amelyben az intézmény, vagy maga a közösség, annak mikroközösségei, kutató, kísérletező közösségek, akik nagyhangsúlyt fektetnek az ismeretek minél tágabb spektrumon mozgó begyűjtésére szintetizálására, analizálására (Varga, 2007). Az 1990-es évek óta szakmai diskurzusokban élénken megtalálható cselekedtető, vagy cselekvő pedagógiákkal szemben szkeptikus Jensen és Schnack, 1997, Breiting, Mogensen 1999), illetve elutasítja azon radikális, mélyökológiába ágyazott pedagógiai paradigmát is, amely a premodernitásban, vagy az abba való visszatérésben keresi az aktuális kérdésekre a választ (Moncarz on Deep Green Bush School 2018, 2019).

A mára már feledésbe merülő természeti nevelés hívószavait „a természetben a természettel a természetért" (Kárász, 2015 in Környezeti nevelés és tudatformálás) Morton ökológia fogalmán keresztül parafrazeálva, jelen akció értelmezhető az alábbi módon: „az ökológiában az ökológiával az ökológiáért".

A következőkben (a gyakorlat bemutatása előtt) az „ökológiai akció”, az „interobjektivitás”, a „művészeti nevelés” foglamak tisztázására és az OxIPO séma gyakorlatban történő alkalmazására térünk ki. 


\section{Ökológiai akció}

Az ökológiai akció egy kortárs filozófus, Timothy Morton ökológiával foglalkozó munkásságában került kibontásra, amely nem klasszikus környezetvédelmi gesztust jelent. Jelen esetben az akció a vizsgálódás, megismerés eszköze. Morton ökológia fogalmának premisszája, egyben konklúziója „egy végtelenül bonyolult összekuszáltság, amelyben minden, mi magunk emberek is létezünk" (Morton 2010, 2018). Az elmélet pedagógiai akcióba való beépítésének köszönhetően az akció jelen esetben a megismerést, „olvasást” lehetôvé tevő oktatási-nevelési forma, amely abból a feltételezésből indul ki, miszerint a valóságunkat alkotó elemek között bonyolult látható és láthatatlan összefonódások léteznek. Ezért azok önmagukban történő vizsgálata nem lehetséges, csak az együttes, komplexitásra törekvő megközelítés szolgálhat a valósággal összeegyeztethető eredményekkel.

\section{Interobjektivitás}

A fogalom először Harman által került kidolgozásra, miszerint: a látszólag egymástól elkülönülő tárgyak, csak látszólag különülnek el, illetve nemcsak akkor fejtik ki hatásukat, amikor éppen használatban, jelen vannak (Harman 2002). Morton ezt a fogalmat saját ökológiai munkásságában a buddhizmussal egészíti ki és azt mondja, hogy a tárgyak visszacsillanak, megjelennek a közvetlen közelükben, vagy tőlük távolabb álló tárgyakban, azok minőségében, tulajdonságaiban (Morton 2013). Példája erre a globális felmelegedés, amely láthatatlan ugyan a szem számára, mindössze annak szimptómái mentén válik érzékelhetővé, megtapasztalhatóvá, időjárás, mezőgazdaság, táplálkozás, elhalálozási ráta formájában (Morton 2012).

\section{Müvészeti nevelés}

Havas és Lehoczky mûvészeti nevelés, környezeti nevelésben betöltött szerepének fontosságát az esztétikai dimenzión keresztül ragadják meg (Havas 1994, Lehoczky 1999) Elsősorban a természet, környezet formavilágának, színeinek, harmonikus elrendeződéseinek értelmezésével, megfigyelésén keresztül kötik egymáshoz a két területet. A mûvészeti nevelés, ahogy maga a professzionális képzőművészeti praxis többre hivatott, mint látásra nevelés, forma-színérzék fejlesztés (v.ö.: Mező és Mező, 2019). Ezért jelen esetben a mûvészeti nevelés a maga végtelenül adaptív tulajdonságának köszönhetően képes lehet a megfigyelés, tanulás egy olyan tág spektrumának a létrehozására, amely meghaladhatja más, főként a szigorú természettudományos tárgyak merevségét, vagy kiegészítheti, támogathatja azokat. Jelen esetben a mûvészeti nevelés tevékenysége nem egy környezeti, gazdasági problémának a megörökítése a művészet eszközeivel (rajzi, festészeti, szobrászati, intermediális eszközök), hanem egy létezô probléma minél tágabb értelemzési lehetôsége, akár meta szintű olvasása.

\section{Az OxIPO-modell \\ alkealmazása a gyakorlat során}

Az akció során a Mező-féle OxIPO-modell (a tanulás egy szervezés, bemenet, feldolgozás, kimenet komponensekkel jellemezhető infomrációfeldolgozási folyamat - Mező, 
2011) alkalmazható a megismerô, olvasási, meta olvasási pedagógiai kísérletben. Inputként, bemeneti jelként alkalmazhatjuk a szennyezés jelenségérôl szóló információt, a process, tehát feldolgozási folyamat magának a jelenségnek a szóbeli divergens, több személy általi keretezése. Az output, tehát a kimenet az elsajátított, beépített ismeret. A tanulási, olvasási folyamat összetett, divergens és kiszögelésekben gazdag feldolgozásának eredményeként pedig akár produktív (információt termelő) tanulás is kialakulhat.

\section{A gyakorlat bemutatása}

Az alábbiakban a Vízkép-ökológiai akció célja, személyi feltételei, tartalmi vonatkozásai és eredményei kerülnek bemutatásra.

\section{Célok}

Az akció átfogó célja: a környezeti nevelés szakirodalma által megfogalmazott múvészeti és környezeti nevelés közös keretrendszerét (Havas 1994, Lehoczky 1999) meghaladó koncepció létrehozása, a már meglévő és használható elemek, módszerek (akció, terepgyakorlat, kísérletezés) megtartása, illetve meghaladásra, fejlesztésre szoruló fogalmak átkeretezése (megismerés, tudomány, természet, környezet, lokalitás-globalitás, esztétikai nevelés, szépre-harmóniára nevelés) (Morton 2010).

Cél volt az is, hogy a mûvészeti nevelés, a kortárs képzőművészet végtelenül adaptív jellege jóvoltából szakítsunk azokkal a pre- konceptuális berögződésekkel, amelyek az esztétikai dimenzió, újraalkotás, leképzés determinisztikus értelmezésében látja a művészeti nevelés, környezeti nevelés területén kamatoztatható szakterületi adottságát.

Lényeges szempont volt az is, hogy a gyakorlat részét képezze egy valós környezeti, városépítészeti, természeti probléma detektálása, diagnosztikája pedagógiai-múvészetifilozófiai eszközök felhasználása által (ezzel együtt: alternatíva biztosítása a mimézis, tantermi reprodukció, eljátszás lehetőségével szemben).

Cél volt az is, hoyg a sokrétű tartalmi rétegezettség és más jelenségek kontextusába való beágyazottság tényéből kifolyólag az értelmezés, analízis konvergens elrendezése helyett divergens értelmezési keret kialakítására legyen lehetősége a projektben résztvevő tanulóknak, pedagógusoknak. Például: a vizsgált patakvíz képe, minősége, állapota egyrészt a szennyezettség okán egy környezeti etikai, kémiai, biológiai, másrészt egy városépítészeti, harmadrészt gazdasági vonatkozásban vizsgálható kérdés is egyben.

Az interobjektivitás szemelőtt tartása is az akció lényeges eleme volt. A gazdag értelmezhetőség jóvoltából cél volt az interobjektív (egymásban felsejlő, felcsillanó) olvasás, vagy meta-szintű értelmezés állapotának elérése, amely során egy adott jelenség vizsgálata, más jelenségek egyidejű vizsgálatával egyenlő. A vízfelszínén úszó szennyvíziszap, olajos filmréteg például maga a megoldatlan és fenntarthatatlan városépítészeti probléma, vagy a városon belüli hanyatlás, tehát dzsentrifikáció, gettósodás egy vizuálisan is érzékelhetô szimptómája. 
A kognitív folyamat végtelen, akár a kvantumok szintjén is megragadható jellegéből adódóan olyan tárgyak készítését is célul tûztük ki, amelyek egyrészt megfelelnek a művészeti kánon elvárásainak, tehát értelmezhetők műtárgyként, másrészt magukon hordozzák a vizsgált problémát, annak minél több lehetséges aspektuást.

Végül: szándékunkban állt azon képesség kialakítása, amely jóvoltából a projektben közreműködő tanulók megtapasztalják, elsajátítják a valóság, jelenség nem egysíkú, vagy egy dimenziós, hanem interobjektív olvasásának, megismerésének képességét.

\section{A gyakorlat müködtetöi}

A gyakorlat működtetői olyan, részben vizuális mûvészetek, művészeti oktatás, illetve földrajz, biológia, területén dolgozó pedagógusok, főiskolai hallgatók (4 fö), akik intenzíven foglalkoznak a globális válsághelyzet ökológiára, környezetre, emberi viselkedésre, mûvészetekre, oktatásra gyakorolt hatásának kérdésével. Közös jellemzőik: a globális válságjelenség lokális szimptómáinak értelmezésén túl, az azok hátterében álló gazdasági, társadalmi összefüggések feltárása, azok keretezése, a látszólag önálló jelenségek hálóba, vagy hálózatba rendezése, azok közötti finom összefüggések, mechanizmusok megismerésének lehetőségei iránt érdeklődnek. A nap mint nap tapasztalható radikális környezeti, természeti válsághelyzet ellenére igyekeznek objektíven, a szükséges kiszögelések mentén kritikusan viszonyulni a szélsőséges narratívákhoz (például azokhoz a hangokhoz, amelyek egyfajta aszkézist, premodern fordulatot, a romlás előtti időkbe va- ló visszatérést követelnek, vagy tartanak egyedül járható útnak). Másrészt objektíven és kritikusan törekednek hozzáállni az úgynevezett „mérnök”, vagy „techno optimista” attitűdhöz is, amely működésképtelenné tett, cserélhető alkatrészek rendszereként tekint a szóban forgó problémára (Takács-Sánta, 2007). Álláspontjuk megegyezik abban, hogy az ember jelenlegi tudományos, technológiai felkészültsége által csak készül megérteni, megismerni mindazon tényezők összekuszált halmazát, amelyek korunk globális válságjelenségét képezik. Ahogy hasonló megfontolásból megvalósított korábbi akcióik során, ezen gyakorlat esetében sem a tények relativizálásának, bagatellizálásának lehetőségét keresték. Ellenkezőleg: ahogy korábbi közös akcióik (Re-ház, madárlak-madáretető építés, Antropocén-az ember kora? akcióik), úgy a jelenleg bemutatásra kerülő gyakorlat is a pedagógia számára, válsághelyzet értelmezésére keres lehetséges válaszokat. Értelmezésükben a társadalmi, vagy egyre inkább szimbolikus térben zajló diskurzusokkal, mozgalmakkal ellentétben, (amelyek láthatóan nem váltották be a hozzájuk füzött reményeket, így nem idézve elő a várt globális strukturális változásokat) a pedagógiának önmérséklőnek kell lennie a cselekvés értelmezését, keretezését illetően, ezért jelen akció sokkal inkább tekinthető intenzív olvasási, tovább olvasási gyakorlatnak, mintsem klaszszikus környezeti akciónak.

\section{A rész̧tuevö diákok összetétele, elóképzettsége}

A résztvevők köre egy vidéki mûvészeti középiskola 13. évfolyamos (érettségi utáni képzésben tanuló), illetve 12. évfolyamos, 
még érettségi előtt álló diákjaiból állt. Kis létszámú, összesen 14 fős (6 lányból és 8 fiúból összetevődő) közösséghöz indirekt, spontán módon 2 szülő is bekapcsolódott (minimális tárgyi segítségnyújtás, tanácsadás céljából). Előképzettség vonatkozásában a mûvészet szakos tanulók esetében nincs lényeges eltérés. A szakmai, közismereti teljesítmé-nyük terén tapasztalható eltérést leszámítva (legalacsonyabb átlag: 2,1 legmagasabb átlag: 5) ugyanabban a képzésben részesültek, egyikük sem részesült korábbi, általános iskolai tanulmányaik során kiemelt környezeti, környezetvédelmi nevelésben, illetve elmondásuk alapján nem voltak tagjai kimondottan öko-, vagy fenntarthatósági kérdésekkel foglalkozó iskolai közösségeknek. A projekt, vagy akció alapú oktatás-nevelés ugyan nem volt ismeretlen jelenség számukra, azonban a Vízkép-akcióhoz hasonló helyszíni tapasztalatszerzésben, objektum olvasásban, illetve ilyen módon történő műtárgykészítési gyakorlatban még nem volt részük. Fontos megjegyezni, hogy két 12. évfolyamos tanuló rendelkezett minimális filozófiai és pszichológiai ismerettel, amelyet személyes tudomány területek iránti érdeklődésük jóvoltából szereztek. Ez egyrészt azért fontos, mert e két fő gördülékenyebben tudta értelmezni az akció hátteréül szolgáló keretrendszert, illetve felhasznált fogalmakat, másrészt a folyamat során segítséget nyújtott aktív, értő közremúködésük.

\section{A gyakorlat tartalmi elemei, folyamata}

A Vízkép-ökológiai akció az alábbi elemekből építkezett:
Elsőként említhető meg egy elsősorban városépítészeti, csatornázási eredetû prob-léma észlelése (sötét, erősen szennyvíz szagú folyadék esőzések utáni Eger-patakba ömlése), annak megfigyelése (egyszeri eset, vagy általános jelenség). A terület fotózása, patak menti séta, megfigyelés, ismétlődő monitorozás által hasonló szennyezések keresése, probléma lehetséges kitágítása a patak folyásával ellentétes és azzal megegyező irányban (1. ábra).

\section{1. ábra: a szennyezés helye (forrás: a Szerző́)}

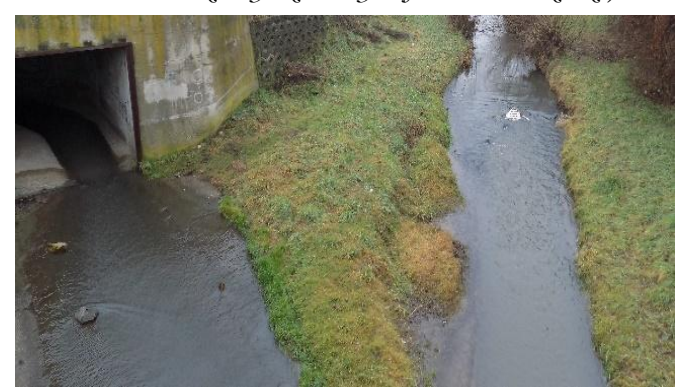

Lényeges programelem volt a projektben résztvevők, téma iránt érdeklődést mutató tanulók, pedagógus kollégák, főiskolai hallgatók megkeresése, megkérdezése, bevonása. A jelenség értelmezése, annak mértékére, jellegére, megoldására adható válaszok összegzése a tanulókkal közösen. Az elméleti keretrendszer, pedagógiai, tantárgyközi értelmezés kidolgozása az érintett pedagógusokkal, hallgatókkal. 
Ezt követte a konkrét cél megfogalmazása: lokális városépítészei, csatornázási probléma megismerése, a probléma kitágítása megismerése gazdasági, környezeti, természeti, biológiai, kémiai, pszichológiai vonatkozásban, amely a művészeti nevelés és környezeti nevelés határterületén jön létre.

Az előzőekre épülve történhetett meg a szennyezett patakvíz leképzése a múvészet eszközeivel (például: szennyezés megfestése, állati tetemek, érzet keltés). A cél a víz, szenynyezés által megváltoztatott minőségének, egyfajta keresztmetszetének dokumentálása. Fontos szempont volt az eddig megszokott mûvészeti, esztétikai keretrendszerrel való szakítás.

A választott alkotói mód a klasszikus tájképfestésnél is használt vakkeretre feszített hordozófelület technikája. Ez eredetileg vakkeretre feszített fehér vásznat jelent, jelen esetben azonban a vászon helyett finom szemcsézettségű szitaháló került felfeszítésre. A háló önmagában vízáteresztô, azonban nem engedi át azokat a fizikai szennyezőket, amelyek a víz felszínén filmrétegként elterülve, vagy magában a vízben úsznak, lebegnek. Másrészt a szemmel nem érzékelhető szenynyezők (nem fizikai) kémiai elemek elszíneződés formájában szintén megjelenhetnek a szűrő felületen.

Ezen a ponton kerülhetett sor az elkészített hálós kereteknek a szennyezés helyszínére történő szállítására és csatornába történő installálásáraa, valamint a víz szűrésére, a víz „keresztmetszeti képének” elkészítésére (2. ábra).

Ekkor megtörténhetett a vízmintagyűjtés az Eszterházy Károly Egyetem Természettudo- mányi Karán elvégzendő laboráns vizsgálathoz. A szűrés során megtörtént a jelenség megbeszélése, olvasása és tovább olvasása környezetre, természetre gyakorolt hatásainak vonatkozásában.

\section{2. ábra: a vakkeretre fesquitett bálók helyszinre} szállitása (forrás: a Szerzőo)

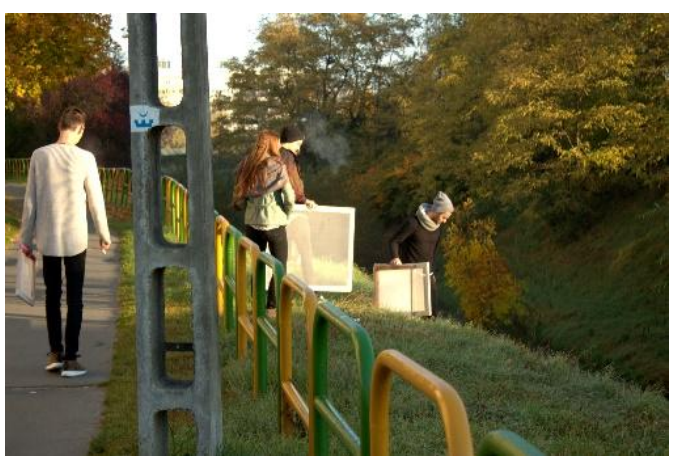

Következzék itt néhány példa az interobjektív olvasási kísérlet során felmerült megközelítésekre! A kérdés az alábbi módon volt összegezhető: Mi minden válik láthatóvá egy szennyezés megfigyelése során, magában a szennyezésben? Lehetséges válaszok például:

1. Ismétlődő, így általánosítható probléma megléte mögött húzódó politikai, gazdasági okok. Külvárosi rész (Északi lakótelep), távol a tőkeképzésben érdekelt és domináns belvárosi résztől (történelmi belváros, turisztikai központ), ezért állapota másodlagos a döntéshozók számára perifériás jellegének, látómezőből való kiesésének köszönhetően.

2. A városrész leépülésének, dzsentrifikációjának lehetséges oka vagy következ- 
ménye, ami folyamatosan romló közbiztonságot, helyi infrastruktúra hanyatlását, lakásárak irracionális hullámzását, megélhetés problematikusságát jelenti.

3. Környezeti, természeti hatások a helyi vízi állat-és növényállományra. A hanyatló élővilág, kellemetlen szennyvíz szag emberi érzékszervekre, közérzetre, pszichére gyakorolt esetleges hatásai.

A hálók kiemelése, szárítása, műhelybe történő visszaszállítása, és közegészségügyi elvárásoknak megfelelő szigetelése áttetsző bevonattal jelentette a következő lépést.

Az záróteendők között volt az akció közös megbeszélése, önrefelxiók, észrevételek, tapasztalatok megosztása, elkészült dokumentációs anyagok közös kiértékelése. A klasszikus esztétikai, képi minőséggel rendelkező tárgyak további sorsának megbeszélése. Ennek eredméyneként vált lehetôvé a jelentkezés egy jótékonysági képzőművészeti aukcióra Budapesten a Fiatal Képzőművészek Stúdiójának Egyesületénél (FKSE), majd a mûtárgy Budapestre szállítása, és a kiállítás megnyitót követô meglepő és nem várt értékesítése. A befolyt összeget felajánlottuk a jótékonysági kiállítást szervező, aukciót lebonyolító FKSE számára (3. ábra).

\section{3. ábra: a kortárs jótékonységi aukción értékesitett} mü (forrás: a Szerrố)

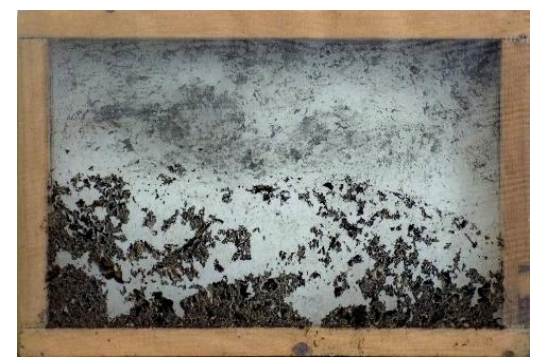

\section{A projekt továbbfejlesztésének lehetöségei}

A fejleszthetőség jelen esetben kétféle képpen is értelmezhető. Egyrészt vonatkozhat a technikai megvalósítás területére, ami a hálók csatornamederben történő installálhatóságának, majd sterilizálásának problémáját jelenti. Másrészt a projekt egy esetleges ismétlés, vagy más általi megvalósítása terén is felvet releváns kérdéseket, amelyek az alábbi észrevételekben foglalhatók össze, és amelyek részben közösen kerültek megfogalmazásra:

1. A már meglévő és interpretált, újonnan alkotott fogalmak pontosítása az elméleti háttér megalkotása számára. A környezeti nevelés tipológiájának mely elemei kerülhetnek beépítésre, illetve mi szorul meghaladásra.

2. Az előzőleges tanári felkészülés, illetve eleve adott tanári-tanulói ismeretek további kitágítása, a magasabb szintű tovább olvasás érdekében, amely történhet a probléma még tágabb keretezése, vagy más területeken tevékenykedő szakemberek bevonásával, akik saját területeik releváns vonatkozásaival tágíthatják az értelmezése lehetôséget.

3. A minőségi dokumentálás kérdésének megoldása, és a szükséges eszközökkel, szakismeretekkel rendelkező személyek bevonása az utólagos bemutathatóság, prezentálhatóság érdekében.

4. Átfogóbb laboráns vizsgálat lehetőségének a megteremtése, hasonló akciók eredményeinek kiértékelése során. A vízből vett minta nem mutatott a határértékekhez viszonyítva szignifikáns eltéréseket, magasabb szám a nitrit, arzén tartalom mérésénél jelentkezett. A laboráns vizsgálatot végző személy elmondása alapján a felhasznált eszközök hozzájá- 
rulhattak az érzékelhető körülményeknek ellentmodnó eredmények létrejöttéhez.

5. Kommunikáció a nyilvánosság felé, a kompetens és érintett szervek a helyi közösség, lakosság informálása a közvetlen közelükben zajló iskolai akció fontosságáról. Akár a helyi közösség bevonása a diskurzusba, amely tovább színesítheti az olvasási lehetôségeket.

\section{Eredmények, tapasztalatok}

Az intézményben zajló, szükséges ingerekben szegény, így motiváció generálására sok esetben alkalmatlan tantermi, műtermi, múhelyi munkával ellentétben az akció a maga kellemetlen kondíciói, közegészségügyi kockázata ellenére is motiválóan hatott szokatlan, eddig ismeretlen jellege ellenére. A probléma fotó, videó, beszámoló alapú indirekt megismerése helyett a valós fizikai, szenzoros jelenlét nagy segítséget nyújtott egyfajta miliő megteremtésében, amelyhez úgy gondolom a digitális tantermi reprodukció és tanári narratíva nem lett volna elegendő (például: szagok, anyagok minősége, hang-, fényeffektusok a csatornarendszerben).

Az interobjektív olvasás, tehát egy adott jelenség értelmezési terének szándékos, vagy tanári mentoráció-navigáció általi kitágítása a tankönyvekben megszokott, szúk értelmezéssel, definiálással ellentétben nem lehetetlen, vagy felesleges. Az olvasás, tapasztalatszerzés, tanulás, ezen módjával szembeni szkeptikusokban felmerülhet a kritikus kérdés, miszerint hasznos, megtermékenyító lehet-e a megismerés, adatszerzés ezen módja, nem vezeti-e túlzottan indokolatlan, szóban forgó témához nem szervesen kapcsolódó területekre a figyelmet? Az akció kiértékelése után adható válasz: határozott nem. Amennyiben a tantárgyköziség, interdiszcilinaritás valóban elérendő cél (Palmer és Neal, 1998; Havas, 1994; Orr, 2004; Jensen és Schnack, 1997), akkor az első lépések egyike az ilyen és ehhez hasonló gyakorlatok irányába való elmozdulás lehet (a maga összetettebb, pedagógusi munkavégzésre nagyobb nyomást helyező jellege ellenére is).

Az interobjektív olvasás használata, további alkalmazása mellett szól az a tény is, hogy elősegíti, támogatja a komplexitásra törekvő, rendszerszintű narratívákat, azok hálózatba rendeződő bonyolult struktúráinak megismerését, amelyet a XXI. század oktatása, illetve maga a környezeti nevelés is megkövetel (Havas, 1994; Varga, 2007). Egy, az általunk vizsgált vízszennyezéshez hasonló lokális jelenség kitágítása, gazdag összefüggésrendszerbe helyezése, megtámogathatja az olyan globális kontextusban kezelendő probléma értelmezését, mint amilyen a globális felmelegedés és az ahhoz kapcsolódó számos, klimatológiai, mezőgazdasági, biológiai, egészségügyi mezőgazdasági, pszichológiai szimptóma.

A hálók által rögzített kép, vagy keresztmetszet, illetve maga az elkészítés módja, körülményei a művészeti nevelés azon sztereotíp megítélését, illetve megközelítését is jócskán kitágították, amelyek azt szigorúan az esztétikai dimenzión belül értelmezik. A mûtárgykészítés jelen esetben nem az elegáns kijelentések, érzetek megfogalmazásának a módja volt, hanem a megismerés, feltérképezés, kérdések megfogalmazásának eszközeként funkcionált. 
Művészeti nevelés vonatkozásában az nem állítható tényszerűen, hogy az akció igazodott-e Morton múvészetek szerepéról alkotott elméletéhez, amely egyfajta jövőbeliségről, jövőből jelen számára megfogalmazott kérdésekből konstruálódik a kísérletezés által (Morton, 2018). Tény azonban, hogy Morton ökológia elmélete megvalósult (Morton, 2010) a megszokotthoz viszonyított gazdag értelmezési keret jóvoltából. A tárgyak az installáció/prezentáció lehetőségeit is kitágították. Két alkalommal kerültek bemutatásra, egyszer a falon szimmetrikus elrendezésben, második esetben a földön az eredeti csatornába helyezett folyásirányt követő formában. Utóbbi a speciális térigények ellenére, az eredetivel sokkal inkább azonosítható érzet kialakítására volt alkalmas. Az akció számos további ötletet generált, az egyik legizgalmasabb ezen kvantum olvasatokra, vagy makro ökológiák megfigyelésére lehetôséget biztosító koncepciók közül az úgynevezett „Nano galéria” névre hallgat. Az ötlet lényegében az emberi köröm alatti makro ökológiák, vizsgálatára, azok gazdagságára fókuszál úgy, hogy kísérletet tesz azok vizualizációjára.

Szennyezésmegszűntetés vonatkozásában az akció nem tekinthető eredményesnek, de ahogy ez a bevezetésben leírásra is került, eszközei, virulenciája jóvoltából erre eleve nem is vállalkozhatott a csoport. A csatornából patakvízbe jutó szennyezés a hibás csatornázási, városépítészeti munka, épített és nem épített terek egymásmellettiségről alkotott káros elképzelések egy szimptómája, amelyből a patak mentén számtalan található. Annyi azonban elmondható, hogy egy ehhez hasonló, alacsonyköltségvetésű, önkormány- zati, vagy lokális, lakossági felügyeleti szerv ellenőrzése alatt álló hálós szűrőrendszer beépítése minőségileg (vizuálisan, fizikai szenynyezőkkel szemben) elősegítheti a természetes vizek tisztántartását. Speciálisan kezelt szűrőhálók a kémiai szennyezők egy részét is kivonhatnák.

\section{Konklúzió}

A projekt elején megfogalmazott célok vonatkozásában az akció sikeresnek tekinthető. A résztvevők kíváncsiak, motiváltak voltak a megszokott műtermi mútárgykészítéstől alapvetően eltérő alkotói mód jóvoltából. A mûtárgykészítés ezen szokatlan módja (merítés, szűrés) a jelenség megismerésének, kitágításának lehetőségét is magában hordozta, így határozottan állítható, hogy tanulási folyamat is végbement a konzervatív tanórai körülményekkel való szakítás ellenére. Ugyan írásos kikérdezésre, dolgozat, teszt formájában nem került sor, így empirikusan nem igazolható, hogy az információszerzés interobjektív módja intenzívebben, vagy mélyebben rögzítette-e az elhangzott magyarázatokat, vagy esetleg a tanórai tanulás értékvesztését is meghaladta az. Azonban a tanulók és hallgatók, illetve projektet szervező pedagógusok visszacsatolásai pozitívak voltak, számos fejlesztési észrevétel fogalmazódott meg elmélet és gyakorlat vonatkozásában egyaránt.

Külön kiemelendő siker az akció befejezéseként a tárgyak értékesítése a műtárgypiacon és aktív szerepvállalás egy nagy múltú, országos és nemzetközi szakmai presztízzsel rendelkezőszervezet támogatásában. 


\section{Irodalom}

Breiting, S. and Mogensen F. (1994): Action competence and environmental education, Letöltés: 2019.11.01. Web: https://ensi.org/ global/downloads/Publications/401/Brei ting $\% 20$ Action $\% 20$ Competence $\% 20$ and $\% 20$ EE.pdf)

Bryant, L., Srnicek, N. and harman, G. (Eds.)(2011): The Speculative Turn. Melbourne: re.press.

Havas P. (1994): Érték és értékátadás a környezeti nevelésben. Iskolakultúra, IV. évf., 9. szám, 3-15. Letöltés: 2019.11.18. Web: http:/ / real-j.mtak.hu/11134/9/Iskolakul tura_1994_9.pdf)

Harman, G. (2002): Tool-being, Heidegger and the Metaphiycs of Objects. Chicago (USA): Open Court Publishing.

Jakab Gy. és Varga A. (2007): A fenntarthatóság pedagógiája. L'Harmattan Kiadó, Budapest

Jensen, B.B. and Schnack, K. (1997): The action competence approach in environmental education. Environmental Education Research, 3:2, 163-178. doi: 10.1080/1350462970030205 Letöltés: 2018.11.10. Web: https://ensi.org/ global/downloads/Publications/405/Jens en $\% 20$ Action $\% 20$ Competence $\% 20$ Appro ach $\% 20$ in $\% 20$ Environmental $\% 20$ Educati on.pdf)

Kárász I. (2015): A környezeti nevelés története, céljai és eszközei. Környezeti nevelés és tudatformálás. In: Mika J. és Pajtókné Tari I. (szerk.): Környezeti nevelés és tudatformálás. Tanulmányok az. Eszterbáay Károly Föiskola múhelyeiböl. Líceum Kiadó, Eger. 37-52. o.
Lehoczky J. (1999): Iskola a természetben, avagy a környezeti nevelés gyakorlata. Raabe Klett Könyvkiadó Kft, Budapest

Mező F. (2011): Tanulás: diagnosz̨tika és fejlesztés az. IPOO-modell alapján. $\mathrm{K}+\mathrm{F}$ stúdió Kft., Debrecen.

Mező F. és Mező K. (2019): A müvészetdiagnosztikai méröeszkö̈z fejlesztésének koncepciója. Magyar Képzőművészeti Egyetem, Budapest

Moncarz J. (s.a.): What is education for? Letöltés: 2019.11.20. Web: http://www.deep greenbushschool.org/uploads/4/2/7/6/ 42762299/what_is_education_for__moncarz.pdf)

Morton T. (2007): Ecology without Nature, Rethinking Environmental Easthetics. , Cambridge: Harvard University Press

Morton T. (2017): Humankind, Solidirity with Non-Human People. USA: Verso

Morton T. (2010): The Ecological Thought. Cambridge, USA: Harvard University Press doi: 10.2307/j.ctvjhzskj

Morton T. (2011): Dawn of the Hyperobjects 1.mp4 Letöltés: 2019.11.08. Web: https://www.youtube.com/watch?v=NS 8b87jnqnw)

Morton T. (2013): Hyperobjects, Philosophy and Ecology After the End of the World. Minneapolis: Univerity of Minnesota Press

Morton T. (2016): Dark ecology For a Logic of Future Coexistence. USA: Columbia University Press

Morton T. (2018): Being ecological. USA: MIT Press.

Orbán S, Ujjfaludi L. és Mika J. (2015): Bolygónk környezeti problémái. Környezeti nevelés és tudatformálás. In: Mika J. és 
Pajtókné Tari I. (szerk.): Környezeti nevelés és tudatformálás. Tanulmányok az Eszterbáay Károly Föiskola mühelyeiböl. Líceum Kiadó, Eger. 17-35. o.

Orr, W.D. (2004): Earth in mind: On Education, Environment and the Human Prospect. USA: Island Press
Takács-Sánat, A. (szerk.) (2007): Paradigmaváltás ?! Kultúránk néhány alapvető meggyôződésének újragondolása. L'Harmattan Kiadó, Budapest

Palmer, J. and Neal, P. (1998): A környezeti nevelés kézikönyve. Körlánc Egyesület, Budapest 